\title{
Use of multicriteria analysis to define priority areas for reforestation in the Piranga River Basin, MG, Brazil
}

\section{Uso da análise multicritério para definição de áreas prioritárias para reflorestamento na Bacia do Rio Piranga, MG, Brasil}

Caroline de Souza Cruz Salomão ${ }^{a}$

Luiz Gustavo de Souza Paulab

Marcos Antônio Timbó Elmiroc

aPrograma de Pós Graduação em Análise e Modelagem de Sistemas Ambientais, Universidade Federal de Minas Gerais, UFMG, Belo Horizonte, MG, Brasil E-mail: carolinescsalomao2@gmail.com

${ }^{b}$ Programa de Pós Graduação em Análise e Modelagem de Sistemas Ambientais, Universidade Federal de Minas Gerais, UFMG, Belo Horizonte, MG, Brasil E-mail: Igustavosouzap@gmail.com

'Programa de Pós Graduação em Análise e Modelagem de Sistemas Ambientais, Universidade Federal de Minas Gerais, UFMG, Belo Horizonte, MG, Brasil

\begin{abstract}
The Piranga River Basin is one of the main sub-basins of the Doce River, being one of the most historically explored, which culminated in an emblematic episode, the rupture of the mining tailings dam in Mariana. Those responsible for the damage had to develop solutions to repair the territory, mainly the definition of priority areas for conservation. One factor to consider for this definition was the institution of protected spaces in rural properties, such as the Permanent Preservation Areas (PPAs), consolidated by the new Forest Code (Law No. 12,651 / 2012). For the allocation of intervention areas, the Multicriteria Analysis was adopted, widely used in decision-making processes. The results showed that the southeast area of the Doce River State Park is more likely to receive initiatives to restore native vegetation. The opposite occurs in the more urbanized regions of the basin, which are also coincident with the steepest areas.
\end{abstract}

Keywords: Multicriteria analysis. Permanent preservation areas. Reforestation of native vegetation. Piranga River Basin.

\section{RESUMO}

A Bacia do Rio Piranga é uma das principais sub-bacias do Rio Doce, sendo uma das mais exploradas historicamente, que culminou em um episódio emblemático, o rompimento da barragem de rejeitos de 
mineração em Mariana. Os responsáveis pelo dano precisaram desenvolver soluções para reparação do território, destacando-se a definição de áreas prioritárias para conservação. Um fator a considerar para essa definição foi à instituição de espaços protegidos em imóveis rurais, como as Áreas de Preservação Permanente (APPs), consolidadas pelo novo Código Florestal (Lei no 12.651/2012). Para alocação das áreas de intervenção foi adotada a Análise Multicritério, amplamente utilizada em processos de tomadas de decisão. Os resultados mostraram que as áreas a sudeste do Parque Estadual do Rio Doce apresentam maiores propensões a receber iniciativas de restauração de vegetação nativa. Ocorre o contrário nas regiões mais urbanizadas da bacia, que coincidem, também, com as áreas de maior declividade.

Palavras-chave: Análise Multicritério. Áreas de preservação permanente. Reflorestamento de vegetação nativa. Bacia do Rio Piranga.

\section{INTRODUCTION}

The management techniques concerning the planning practices are fundamental for development of environmental nature projects, either to generate knowledge about the considered territories or to organize the resources and formulate the most appropriate proposals and decisions for the work. In general, such planning practices include documents and materials that make up a diagnosis for first analyzes. For building the subsequent phases, focused on the prognosis, it is pertinent to adequately define the criteria that will justify the variables observed in the diagnosis.

This process becomes complex when the number of actors involved and interested is large. To overcome these types of difficulties, some techniques have been developed in order to simplify this organization of information and determining where environmental actions would need to take place. The use of such tools becomes even more important taking into account geographic sections of considerable extension, such as river basins.

Another ecological and regulatory issue to be considered when defining priority areas for conservation in river basins is the institution of protected spaces within rural properties with the general objective of compensating for the improper economic uses developed in these properties. In addition, several environmental experts emphasize that public areas under protection are insufficient for the conservation of the planet's biodiversity, another strong justification for the institution of these territories (GOTTFRIED et al., 1996).

Thus, the new Forestry Code (Law No. 12,651 / 2012) included the consolidation of two instruments for the restoration and sustainable use of native vegetation within rural properties, the Permanent Preservation Areas (PPA) and the Legal Reserve (RL). The current environmental scenario is one of intense degradation and exploitation of these areas, whether due to urban occupation or agricultural activities. Therefore, actions for the environmental restoration of these systems are necessary in order to restore them to their original conditions and so that they can perform the ecological function for which they were created.

Nunes et al, 2017, classified the forest restoration process into three groups: passive, intermediate and active, depending on the strategy that will be adopted. Natural regeneration is mentioned as a passive method, the conduction of regeneration and its enrichment is considered an intermediary method, and the reforestation of species with or without economic purpose is taken as an active method. The focus of the study is reforestation by using species with no economic purpose.

In this sense, the multicriteria analysis has been widely used in order to simplify certain decision making processes (FRANCO et al., 2013). Many scientific investigations such as Ferraz and Vettorazzi, 2003; Valente, 2005; Vettorazzi, 2006; Sartori, 2012; Uribe, 2014; Francisco et al., 2008; Valente and Vettorazzi, 2017, have already developed studies to define priority areas for reforestation, without economic ends, using multicriteria analysis as a tool for this choice, and have had satisfactory results in their research. 
It is worth mentioning that, for the restoration of PPAs located in the study area, some premises are assumed and may guide the choice of variables and the process of multicriteria analysis. PPAs located close to urban centers or near highways have a history of greater degradation and for this reason should be prioritized. On the other hand, some geographical conditions must be taken into account. Areas with more fertile soils will be prioritized because they are easier to complete the restoration process, as well as areas located on a higher slope and with soil more susceptible to erosion should be prioritized because they present a strong tendency to degrade with anthropic and natural actions. Finally, this article aims to identify priority areas for reforestation in PPAs located in the Piranga River Basin.

\section{METHODOLOGY}

The study methodological approach was divided into four steps, the first being dedicated to the geographic characterization of the section under study, the second to the regulatory status necessary for analysis, while the third and fourth, explaining the model in focus, its methodology, processing, variables and weights. Following is an organization chart showing each of the steps and their relationships (Figure 1).

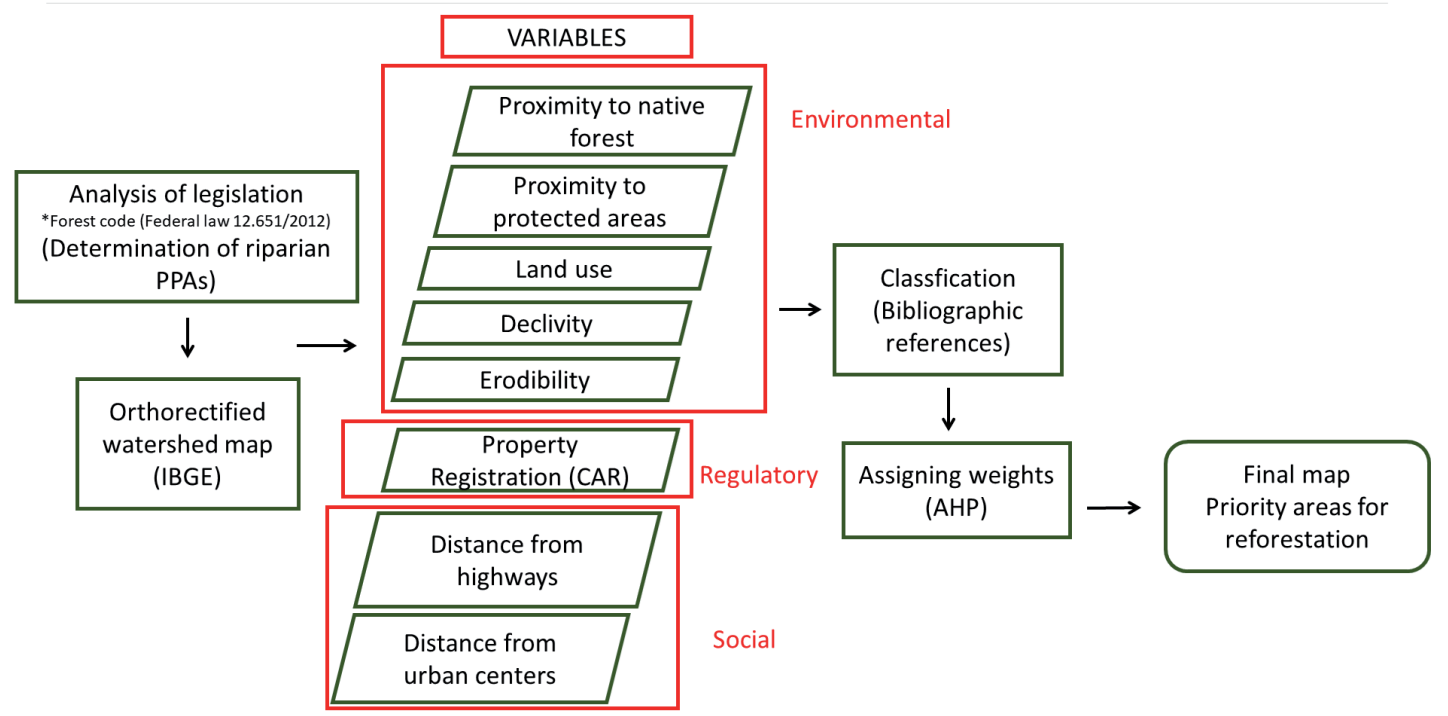

Figure 1 | Methodological organization chart

Source: The authors (2018).

\subsection{STUDY AREA}

The study area is the Piranga River Basin (Figure 2) located in the southwestern part of the Doce River hydrographic basin, in the State of Minas Gerais. In fact, it is the continuation of the Piranga River that receives the name of the Doce River, after receiving the waters of the Carmo River, thus Piranga is effectively the main forming of Doce River. The Piranga basin contains 77 municipalities, 62 of which have their headquarters located within the contribution area. Its population is 711,026 inhabitants $(480,882$ urban, 230,144 rural), according to data from the IBGE / Census 2010, in a total area of 17,562.5 $\mathrm{km}^{2}$, representing about $25 \%$ of the Doce River Basin. The main biodiversity conservation area within the Doce River Basin is the Doce River State Park (PERD), which is also within the Piranga basin area.

The headwaters of the Piranga River are located in the Serra da Mantiqueira, in the municipality of Ressaquinha and its main tributaries are the Xopotó and Turvo Limpo rivers. It presents two hydroelectric plants along its course - HPP Brecha, in the municipality of Guaraciaba and PCH Brito, in Ponte Nova, in addition to having a relatively intense industrial and productive activity, including mineral production, where the Samarco Mining Company also stands out. 


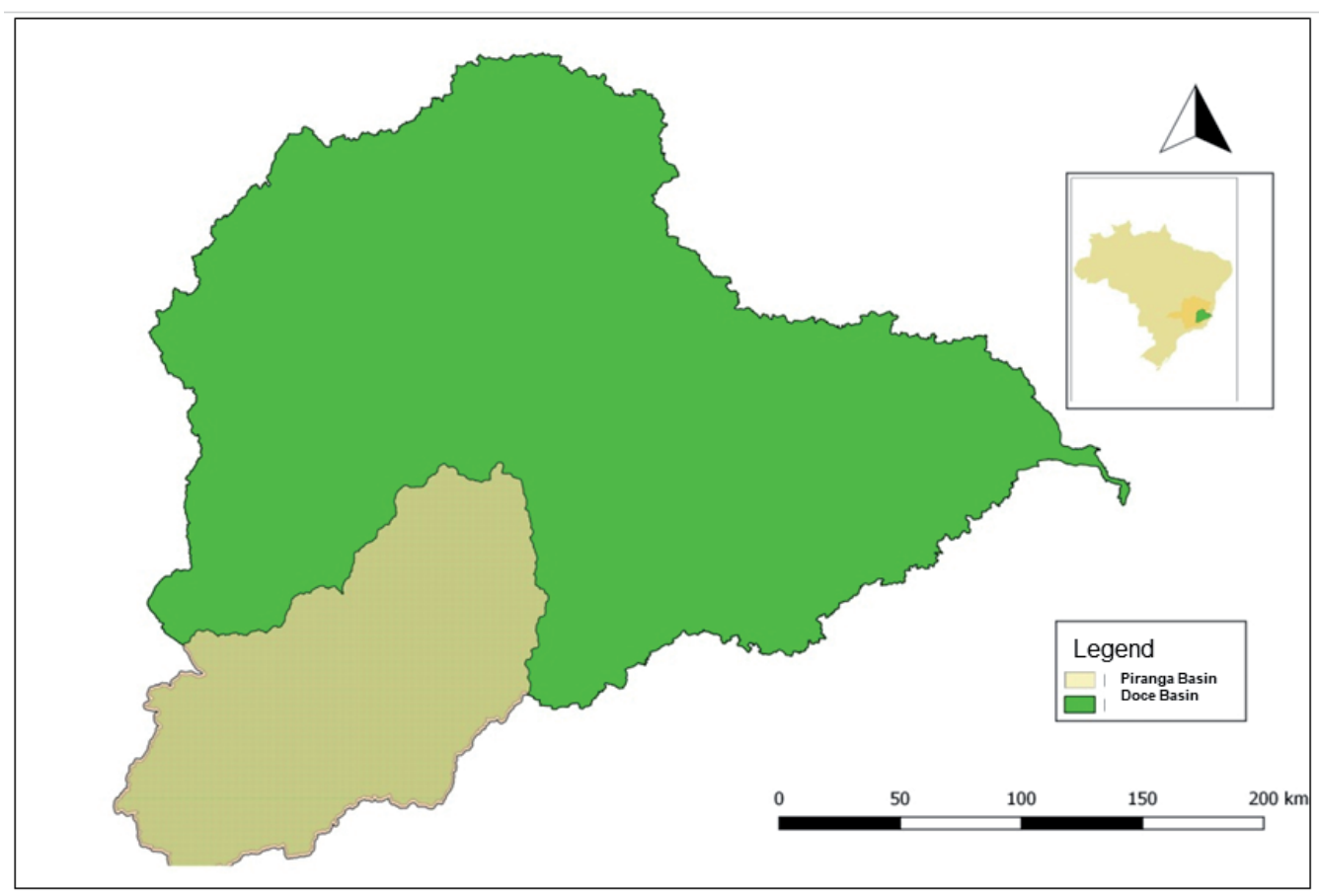

Figure 2 | Piranga River Basin

Source: The authors (2018).

Regarding the predominant economic activities in the Basin, although the entire extension of the Doce River Basin stands out as a milk producer basin, denoted by the high numbers of cattle herds (PPM, 2018), the municipalities northeast of the Piranga River Basin make up an important local economic and logistically strategic region for the entire state of Minas Gerais, named the Vale do Aço region. In addition, between 1920 and 1930 the region was chosen in Minas Gerais to receive the eucalyptus forest culture through government programs and incentives from steel mills. An example was Compahia Siderúrgica Belgo Mineira, and later Acesita, in 1949. The company was a pioneer in the creation of forest services in the region and encouraged other subsidiary companies to operate in the reforestation sector (GUERRA, 1995). Such a profile can be evidenced by the land use and occupation map of the Basin (Modelo Optimizagro. SOARES FILHO et al., 2013), where it is possible to identify large extensions focused on forest plantation (525,766 ha).

As a consequence of this land use and occupation, the Piranga River Basin, as well as all the territory of the Doce River Basin, has a history of intense soil degradation and inadequate use of its natural resources, such as water. According to latest data, the territory in almost all its extension, $83.3 \%$, was classified as moderately degraded or degraded (UFMG; UFV; Fundação Renova, 2018), and the Piranga River Basin is located in this regional section.

In 2015, with the collapse of the Fundão dam, located in the municipality of Mariana and operated by the Samarco mining company, this scenario worsened. According to Pires et al (2017), 40 to 63 million $\mathrm{m}^{3}$ of mining tailings were discharged in the river. The damaging consequences, in addition to the destruction of total or partial districts such as Bento Rodrigues, Paracatu and Gesteira, were losses in biodiversity, economic losses for the riverside populations and intense pollution of the entire Doce River. According to Fernandes et al. (2016), the event was the last straw in a long lasting degradation process, which affected the provision of ecosystem services for more than 1 million people, with an estimated loss of US $\$ 5.21$ billion per year in the region (GARCIA et al., 2017). Forest restoration, the focus of the study, in this area is one of the mechanisms capable of guaranteeing the quality and quantity of water in the Doce River Basin (Figure 3). 


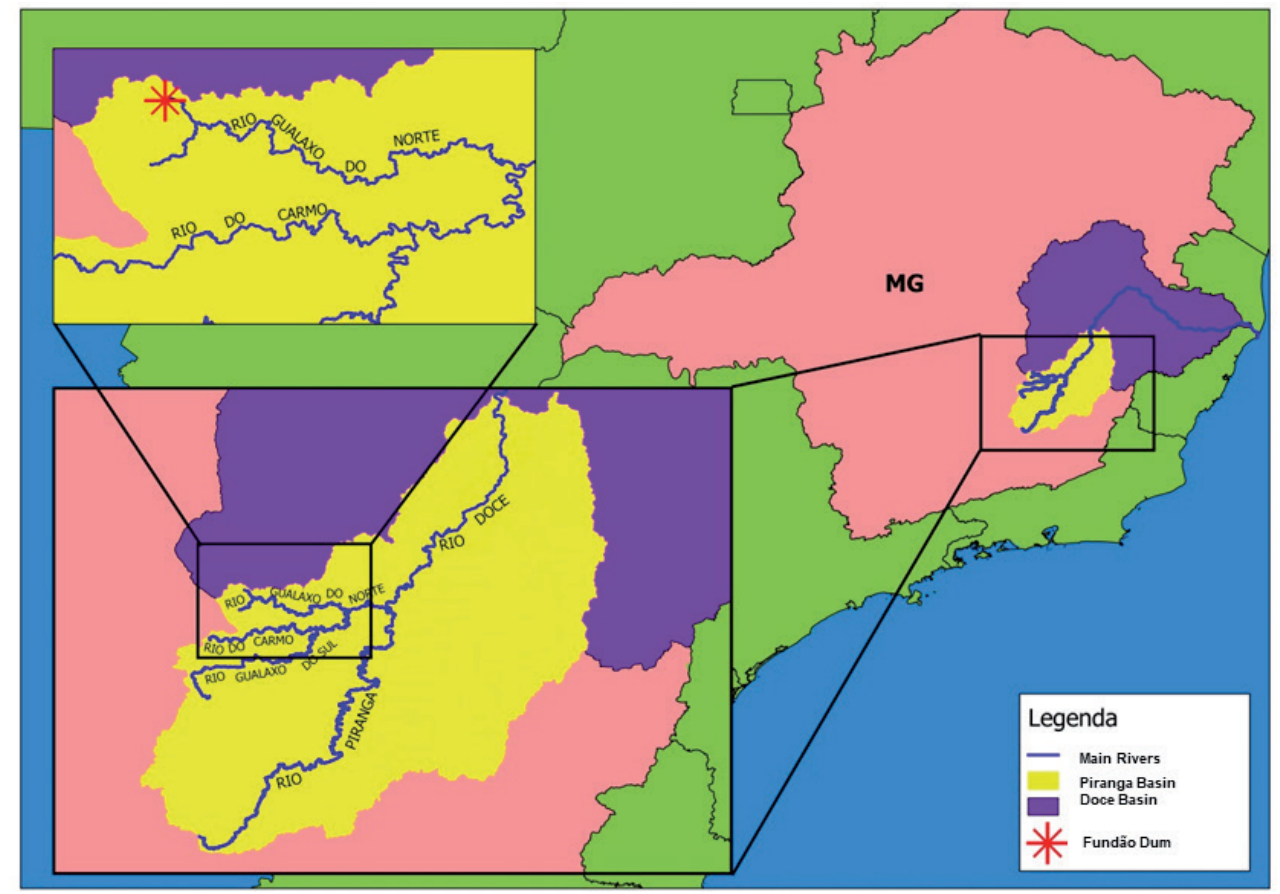

Figure 3 | Tailings mud path from the Fundão dam, municipality of Mariana Source: EPSJV/Fiocruz

\subsection{WATER BODY PERMANENT PRESERVATION AREAS}

The Forest Code (Law No. 12,651 / 2012) brought about the consolidation of two instruments for restoration and sustainable use of native vegetation within private rural properties, the Legal Reserve (RL) and the Permanent Preservation Areas (PPA). According to the Forest Code, PPAs are defined as: "the protected area, covered or not by native vegetation, with the environmental function of preserving water resources, the landscape, geological stability and biodiversity, facilitating the gene flow of fauna and flora, protecting the soil and ensure the well-being of human populations." (Item III, of Article 3 of Law 12.651 / 2012). In this sense, the need to preserve and restore these areas becomes clear.

These areas, whether or not covered by native vegetation, are located neighboring the banks of rivers and other water bodies in bands of varying width, on steep slopes, hill tops, in addition to other locations specified by law. However, the current scenario is one of intense degradation and the occupation of these protected areas for agricultural activities and urban use. According to data from Soares Filho et al (2014), the environmental liability debt of PPAs is approximately 220,000 hectares for the whole of Brazil, and this scenario is even worse in the Atlantic Forest biome, which occupies more than $98 \%$ of the Doce River Basin, where only $12 \%$ to $16 \%$ of native vegetation remains. It is worth mentioning that when assessing the environmental liability with higher resolution images and a denser hydrographic network, this liability may increase.

The new Forest Code (Law No. 12,651 / 2012) also includes changes to the establishment of these PPAs. Article 4, item I defines PPA as being the marginal areas of any natural, perennial or intermittent watercourse from the edge of the regular riverbed, in a minimum width that can vary from $30 \mathrm{~m}$ to $500 \mathrm{~m}$, according to the width of the river between less than $10 \mathrm{~m}$ and more than $600 \mathrm{~m}$, respectively.

Federal Law 12.651 / 2012 also specifies which areas should carry out forest restoration and which method to use. According to device 13 of article $61 \mathrm{~A}$, the forest restoration in the marginal bands can be done, isolated or together, by means of: 
I - conducting natural regeneration of native species;

II - planting native species;

III - planting of native species in conjunction with conducting the natural regeneration of native species;

IV - intercalated planting of woody, perennial or long-cycle, exotic species with native species of regional occurrence, in up to $50 \%$ (fifty percent) of the total area to be recomposed, in the case of rural properties with up to 4 fiscal modules, as well as to demarcated indigenous lands and other areas entitled to traditional peoples and communities that make collective use of their territory (BRASIL, 2012, Art. 3, item I to IV and Single Paragraph).

These three forms of recomposition refer to three restoration processes classified by Nunes et al (2017), as passive, intermediate and active. Passive restoration or natural regeneration is a process of natural succession with minimal human intervention (HOLL and AIDE, 2011). It is a slow but low-cost process. The active, on the other hand, is a process of restoration by total planting with native species without economic ends. This latter technique is the focus of the approach in this article.

In order to a PPA area minimally fulfill its environmental functions, as determined by the Forest Code, its use must be compatible with the previously existing native vegetation preservation regime. In this sense, the mapping of land use and coverage, preferably in high spatial resolution, is an important tool for the analysis of legal compliance in the scale of rural properties and the landscape, as in the case of the Doce River Basin. The National Water Agency (ANA) and the Brazilian Institute of Geography and Statistics (IBGE) provide hydrographic maps of the entire country, but the scale of 1:100,000 or less available in these maps does not allow a detailed analysis of the Doce River Basin. For this reason, the hydrographic network mapping carried out by the Brazilian Foundation for Sustainable Development (FBDS) was used in this study. The FBDS mapping project was carried out through supervised classification of RapidEye remote sensing images for the year 2013, on a scale of 1:10,000, producing maps of land use and coverage on the scale of 1:20,000.

\subsection{MULTICRITERIA ANALYSIS}

Spatial analysis represents one of the most efficient and economical methods in the management of watersheds, especially when it is necessary to carry out a prioritization of areas. In a practical way, it is an integration of different landscape information plans and their characteristics and, or, processes, together with the Geographic Information Systems GIS (VALENTE, 2005). In this sense, the Multicriteria Analysis (MCA) can be highlighted, according to Malczewski (2004), this method can be described as a process that transforms and combines spatial and non-spatial data resulting in a decision.

MCA as a methodology is based on the observation of alternatives in order to clarify issues, where different criteria involved with a given study object are used for identifying the best options available within the analyzed universe (FRANCISCO et al., 2007, apud FRANCO et al., 2013). This analysis is based on criteria that can be factors and restrictions and can refer to individual attributes or the whole set. Despite the selection of criteria as well as the definition of the relative importance of each criterion present a certain degree of subjectivity, the results obtained have shown great coherence with reality (VETTORAZZI, 2006).

Thus, in order to define the MCA weights, which will guide the formulation of the final analysis, one of the main techniques used is the Analytical Hierarchical Process (AHP), where the weights are assigned according to their relative importance. According to Souza et al. (2013), this technique is based on the identification of a decision problem and its decomposition into "sub problems", where each one can be analyzed independently (SILVA JÚNIOR, 2015). 
The attribution of weights to the criteria consists of quantifying the importance of each one in the decision-making process. Several methods have been developed to assist in the definition of the factor compensation weights, including the ordering, the point scale, the point distribution and the method based on the comparison of criteria two by two (RAMOS and MENDES, 2001). To elaborate the comparison matrix, the factors were compared, two by two, using Eastman (2001) as a reference, with the continuous scale of nine points (Table 1). The compensation weights, which express the importance or order of importance of the factors in the decision-making process, were determined based on the literature review from projects developed using the Participatory Technique. The software used to support the application of multicriteria analysis method was ArcGIS.

Table 1 | Intensity of importance between criteria

\begin{tabular}{|c|c|}
\hline Intensity of importance & Definition and explanation \\
\hline 1 & Equal importance - both factors contribute equally for the goal \\
\hline 3 & $\begin{array}{c}\text { Moderate importance - one factor is slightly more important } \\
\text { than the other }\end{array}$ \\
\hline 5 & $\begin{array}{c}\text { Essential importance - one factor is clearly more important } \\
\text { than the other }\end{array}$ \\
\hline 7 & $\begin{array}{l}\text { Demonstrated importance - One factor is strongly favored and its } \\
\text { greater relevance has been demonstrated in practice }\end{array}$ \\
\hline 9 & $\begin{array}{l}\text { Extreme importance - The evidence that differentiates factors } \\
\text { is of the highest order possible }\end{array}$ \\
\hline $2,4,6$ & $\begin{array}{l}\text { Intermediate values between judgments - possibility } \\
\text { of additional commitments }\end{array}$ \\
\hline
\end{tabular}

Source: Adapted from Eastman (2001).

\subsection{DEFINITION OF VARIABLES AND WEIGHTS USED}

In the period from 2002 to 2017, many studies were developed with the objective of identifying priority areas for conservation through multicriteria analysis. In this process, one of the most important methodological steps is the definition of variables. In this sense, the following related researches produced by Borges (2009); Lima et al. (2011); Francisco (2006), Ferraz, S.F.B. \& Vettorazzi, C.A, (2003); Bertoni \& Lombardi (1985), Mannigel et al., (2002) can be highlighted as foundations for choosing variables and others parameters. In addition, Uribe (2014) presents a study in which the choice of variables was made through interviews with stakeholders in an area in the southern portion of Mexico of $11,631 \mathrm{~km}^{2}$ covering wholly or partially (50\%) 124 municipalities. Table 2 below details which variables stand out according to the percentage in which they appeared in the interviews.

Table 2 | Ranking of the criteria used in AHP most mentioned in interviews by stakeholders

\begin{tabular}{|c|c|c|}
\hline Ranking & Criterion & Frquency \\
\hline 1 & Forest fragment distance & 64,3 \\
\hline 2 & Land use and land use changes & 57,1 \\
\hline 3 & Erosion risk (soil erodibility and rain erosivity) & 53,6 \\
\hline 4 & Biodiversity index and natural corridors & 46,4 \\
\hline 5 & Declivity & 42,9 \\
\hline 6 & Crop distance & 39,3 \\
\hline 7 & Demographic density, distance from highways, \\
\hline 8 & distance from rivers & 35,7 \\
\hline 9 & $\begin{array}{c}\text { Distance from human settlements, marginality index } \\
\text { and social capital }\end{array}$ & 32,1 \\
\hline 10 & Depth of soil & 28,6 \\
\hline
\end{tabular}




\begin{tabular}{|c|c|c|}
\hline Ranking & Criterion & Frquency \\
\hline 11 & Distance from protected areas (PPAs) & 10,7 \\
\hline 12 & Soil fertility & 7,1 \\
\hline 13 & $\begin{array}{c}\text { Distance from point sources of greenhouse gas emissions, } \\
\text { migration rate, forest fragmentation, precipitation, } \\
\text { livestock presence, use of biodiversity, temperature }\end{array}$ & 3,6 \\
\hline
\end{tabular}

Souce: Adapted from Uribe et al, (2014).

The action of these stakeholders (landowners, local development associations, etc.) in the decisionmaking process is legitimate and necessary since they are the agents of the forest restoration process, in addition, it ends up bringing a transdisciplinary approach integrating scientific knowledge and local knowledge. These users or interest groups in the basin are directly linked to primary development and / or conservation activities since they enjoy the landscape for their subsistence and are thus directly linked to the generation of ecosystem services. This type of study brings a methodology for building bottom-up policies that are considered more effective for maintaining restored areas, in contrast to the top-down ones that bring strictly technical criteria for discussion (LINDBORG et al., 2008).

Thus, for the present study, variables were chosen and segmented by typologies (ecological, regulatory and social) with the respective study used to support them (Table 3 ).

Table 3 | Chosen Variables for applying in MCA

\begin{tabular}{|c|c|c|}
\hline Criteria & Type & Source \\
\hline Proximity to native forest & \multirow{5}{*}{ Ecological } & $\begin{array}{c}\text { Catelani et al., 2012; Franco; Hernandez; Moraes, } \\
\text { 2013; Orsi; Geneletti; Newton, } 2011\end{array}$ \\
\hline Proximity to protected áreas & & $\begin{array}{c}\text { Orsi; Geneletti, 2010; } \\
\text { Valente; Vettorazzi, 2008) }\end{array}$ \\
\hline Land use & & $\begin{array}{c}\text { Catelani et al., 2012; Franco; Hernandez; Moraes, } \\
\text { 2013; Orsi; Geneletti; Newton, } 2011\end{array}$ \\
\hline Declivity & & $\begin{array}{c}\text { Sartori, 2012; Valente, Valente; Petean; Vettorazzi, } \\
\text { 2017; Valente; Vettorazzi, } 2008\end{array}$ \\
\hline Erodibility & & $\begin{array}{l}\text { Mannigel et al, 2002; BERTONI, J.; } \\
\text { LOMBARDI NETO, F, } 1990\end{array}$ \\
\hline Property Registration (CAR) & Regulatory & Uribe et al., 2014 \\
\hline Distance from highways & \multirow{2}{*}{ Social } & $\begin{array}{c}\text { Fabbro Neto et al., 2014; Valente; Valente; } \\
\text { Vettorazzi, } 2008\end{array}$ \\
\hline Distance from urban centers & & $\begin{array}{l}\text { Fabbro Neto et al., 2014; Uribe et al., 2014; } \\
\text { Valente; Valente; Vettorazzi, } 2008\end{array}$ \\
\hline
\end{tabular}

Source: The authors (2018).

Regarding the assignment of grades and the resulting classification, the areas were segmented into high, medium and low priority for reforestation. Following is a description of some of the criteria and how the grades were assigned according to the authors mentioned:

- Slope: Slope is important because the higher its index, the greater the risk of erosion, which makes the steeper areas more interesting for reforestation, and they also have a lower propensity for agricultural use, which also favors the less flat areas having a higher priority for planting native species.

- Land use: Land use is an indicator of favorable or even inappropriate areas. Examples of areas that do not apply the possibility of reforestation with native species are areas that are already covered by native trees, urban areas, highways, surfaces covered by water. Forestry and traditionally agricultural areas are also not favorable. 
- Susceptibility to erosion: Reforestation is a tool to combat erosion. Therefore, its implementation becomes more interesting in places where this type of problem occurs, considering that where there is erosion, generally, there are also no other types of economic interest.

- Erodibility: Soil erodibility factor K (t.ha.h./ha.MJ.mm) was used as a reference; where: $\mathrm{t}=\mathrm{ton}, \mathrm{ha}=$ hectare, $\mathrm{h}=$ hour, $\mathrm{MJ}=$ mega joule and $\mathrm{mm}=$ millimeter. Its determination requires field visits and validations, according to local conditions. Due to the inexistence of these data, factors estimated from soil characteristics were used, according to Bertoni \& Lombardi Neto $(1985 ; 1990)$ and cited by Mannigel et al $(2002)$.

- Proximity to Native Woods: Reforestation with native species is favored with the proximity of other native forests as this implies ecological connectivity. Thus, we used the variable that makes up the bands of areas that are up to 50 meters away from the native forests already existing in the researched PPAs.

- Proximity to Urban Areas: Generally, the proximity to urban areas is not a favorable factor for the implementation of reforestation of native forest. This is due to the fact that, in general, urban expansion and real estate speculation are factors of considerable pressure and detract from the sustainability of these areas. In this way, we used the variable that composes the bands of areas that are up to 200 meters away from the urban areas present in the surveyed PPAs.

- Proximity to Highways: Similar to that explained in the previous item, proximity to highways is also a factor considered unfavorable. Thus, we used the variable that makes up the bands of areas that are up to 200 meters away from the highways.

After the variables previous study, the maps to be used in the multicriteria analysis were selected. As a process, the selected maps were reclassified by assigning a grade to each class, as previously explained. At the end, weights were given for each of the variables separated according to the authors cited in studies of the AHP method. Table 4 shows the weights used in the final analysis.

Table 4 | Weights used in the final analysis

\begin{tabular}{|c|c|c|c|c|c|c|c|}
\hline & $\begin{array}{c}\text { Proximity to } \\
\text { native forest }\end{array}$ & Declivity & Erodibility & $\begin{array}{c}\text { Proximity to } \\
\text { urban áreas } \\
\text { /roads }\end{array}$ & Land use & $\begin{array}{c}\text { CAR registra- } \\
\text { tion }\end{array}$ & Weights \\
\hline $\begin{array}{c}\text { Proximity to } \\
\text { native forest }\end{array}$ & 1 & - & - & - & - & - & 0,28 \\
\hline Declivity & 5 & 1 & - & - & - & - & 0,12 \\
\hline erodibility & 7 & 9 & 1 & - & - & - & 0,18 \\
\hline $\begin{array}{c}\text { Proximity to } \\
\text { urban areas/ } \\
\text { roads }\end{array}$ & 3 & 3 & 3 & 1 & - & - & 0,17 \\
\hline $\begin{array}{c}\text { Land use } \\
\text { CAR registration }\end{array}$ & 7 & 5 & 7 & 7 & 1 & - & 0,15 \\
\hline
\end{tabular}

Souce: The authors (2018).

\section{RESULTS AND DISCUSSIONS}

The results are different from other works available in the literature, such as those seen in the studies of Francisco (2006) and Ferraz and Vettorazzi (2003) because the great challenge to be faced is the large extension of the chosen basin, since most of the previous research was developed for small basins. Another important difference is the focus on permanent protection areas of watercourses. For this, 
an intense work of remote sensing was necessary due to the great differences in width among the watercourses found in the basin.

In a practical way and observing by a general overview, Figure 4 shows that the areas to the southeast of the Doce River State Park are more likely to receive restoration initiatives with native species. The opposite occurs in the most urbanized regions of the basin and also similarly in those regions with a lower density of native vegetation. The latter are coincident with the areas of the steepest relief.

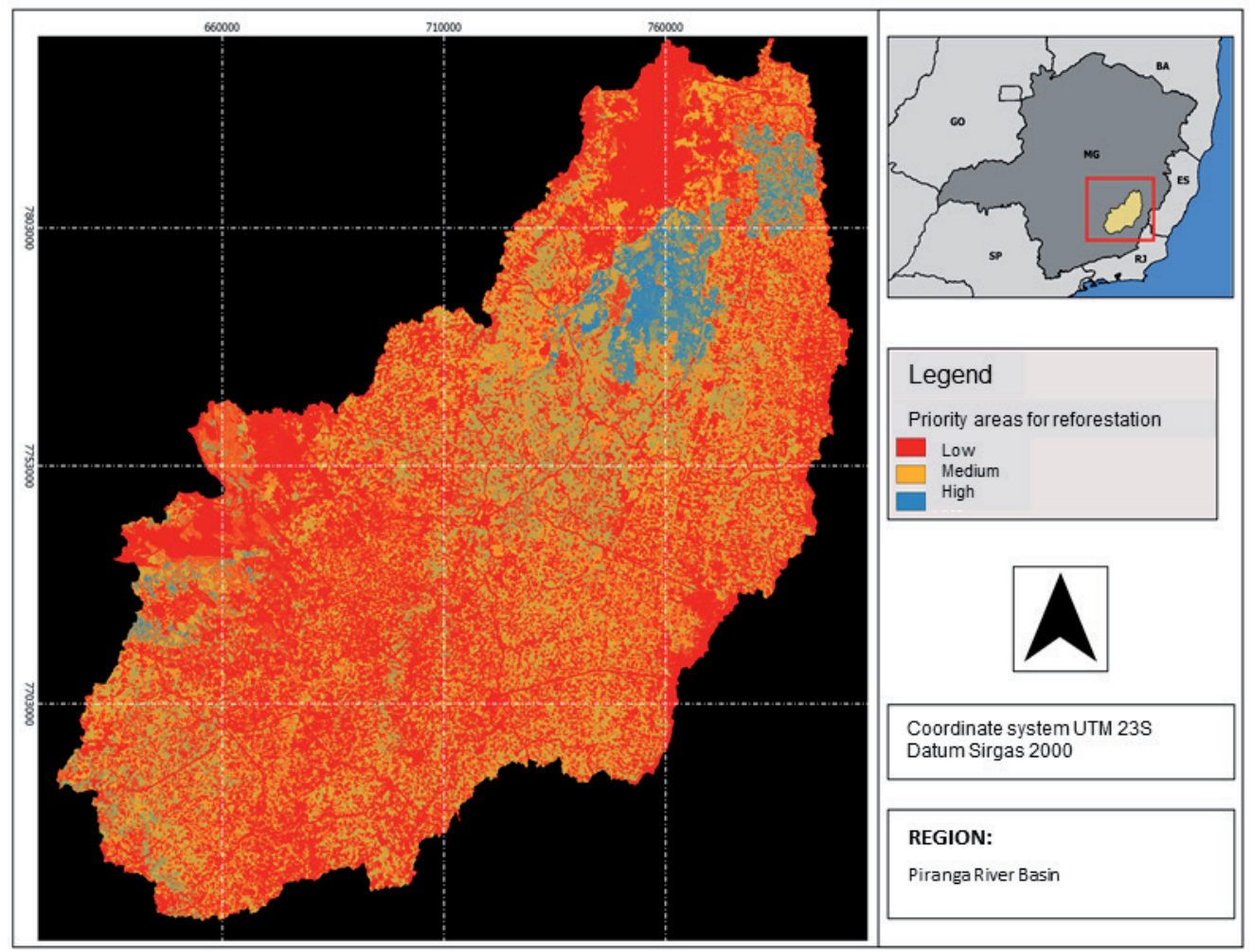

Figure 4 | Map of Priority Areas for Reforestation

Source: The authors (2018).

However, it can be inferred that the present study takes on great importance due to the historical scenario of degradation due to agricultural activities in these protection territories, especially if taken into account the environmental importance of these areas (water recharge, containment of erosive processes, carbon storage, refuge of fauna) and the urgency to reestablish the ecological processes after the tailings dam rupture in Mariana.

Another point to discuss is that reforestation is just one of the restoration strategies that can be mentioned. There are also forest plantations for economic purposes, normally it is a mix of exotic and native species, which can be chosen according to the farmer's desire and also based on the edaphoclimatic characteristics of the territory. In this sense, it is mentioned that each of these formats for restoration has peculiarities that may require other variables than those used in this study and highlight other necessary approaches for the restoration chain, such as the need for investment in nurseries of plant species, training of local labor and other actions already evidenced by other studies (SALOMÃO, 2019).

However, it is necessary to highlight that there was no validation of these results in the field, but some indications can explain about the coherence of the results. One of the criteria considered in the analysis as facilitating restoration was the proximity to native vegetation and land use. At the landscape 
level, connectivity with forest fragments can provide gene flow and accelerate the restoration process (NUNES et al, 2017), this point ends up explaining the concentration of activities around the PERD, which is a State Conservation Unit.

Another issue is regarding the proximity of the road network. Access around the Park is limited, the nearest highway (LMG 760) had a troubled environmental licensing process and only in 2018 the paving process was resumed. A third explanatory point would be the pedological characteristic of the region, the yellow latosol is the dominant classification. These soils are deep and well structured, being attractive for planting native species, but poor in nutrients for crops (CONSÓRCIO ECOPLAN-LUME).

In addition, another necessary issue in this on-site validation is popular participation. This social control is crucial for the realization of restoration. If the rural owner does not feel part of the process, it will be very difficult in the medium and long term to succeed. For this reason, a "bottom up" process is necessary since the construction of public policies such as the Environmental Regularization Program PRA, as discussed in Salomão (2019).

\section{CONCLUSIONS}

The next step of the research to be continued is concerned to the development of some scenarios that may influence public policies. According to (Soares Filho et al 2016) the first scenario to be outlined aims to verify what percentages of priority areas for restoration are within areas in debt according to the Forest Code and so to establish a hierarchy by municipalities. For that purpose, the maps of the aforementioned authors will be retrieved, an analysis of which municipalities are in greater debt will be established and how this issue can be partially solved by the model will be decided. For the second scenario, an assessment will be made of the extent of priority areas for passive restoration and contrasting this with the extent provided for in instruments for the recovery of the Piranga River Basin. It can be mentioned as instruments the Basin Master Plan and the PPAs Recovery Program established in the TTAC - Conduct Adjustment Transaction Term established between public and private entities, thanks to the consequences of the Fundão Dam Disruption.

\section{REFERENCES}

BERTONI, J.; LOMBARDI NETO, F. Conservação do solo. Piracicaba: Ícone, 1985.

São Paulo: Ícone, 1990.

BORGES, L. A. C. et al. Evolução da Legislação Ambiental no Brasil. Rama: Revista em Agronegócio e Meio Ambiente, Maringá, PR, v. 2, p. 447-466, 2009.

BRASIL. Lei № 12.651, de 25 de maio de 2012. Dispõe sobre a proteção da vegetação nativa; altera as Leis no 6.938, de 31 de agosto de 1981, 9.393, de 19 de dezembro de 1996, e 11.428, de 22 de dezembro de 2006; revoga as Leis no 4.771, de 15 de setembro de 1965, e 7.754, de 14 de abril de 1989, e a Medida Provisória no 2.166-67, de 24 de agosto de 2001; e dá outras providências.

EASTMAN, J. R. Decision support: decision strategy analysis. Idrisi 32 Release 2: guide to GIS and image processing. Worcester: Clark Labs, Clark University, 2001.

FERNANDES, G. W. et al. Deep into the mud: ecological and socio-economic impacts of the dam breach in Mariana, Brazil. Natureza \& Conservação, v.14, n. 2, p. 35-45, 2016.

FERRAZ, S. F. B.; VETTORAZZI, C. A. Identificação de áreas prioritárias para recomposição florestal com base em princípios de ecologia de paisagem. Revista Árvore, v. 27, n. 4, 2003. 
FRANCISCO, C. E. F. Áreas de preservação permanente na Bacia do Ribeirão das Anhumas: estabelecimento de prioridades para recuperação por meio de análise multicriterial. Dissertação (Mestrado) - Instituto Agronômico de Campinas (IAC), 2006.

FRANCISCO, C. E. S. et al. Análise multicriterial na seleção de bacia hidrográfica para recuperação ambiental. Ciência Florestal, v. 18, n. 1, p.1-13, 2008.

FRANCISCO, C. E. S. et al. Espacialização de análise multicriterial em SIG: prioridade para recuperação de Áreas de Preservação Permanentes. In: XIII SIMPÓSIO BRASILEIRO DE SENSORIAMENTO REMOTO. Florianópolis. Anais... São José dos Campos: Inpe, p. 2643-2650, 2007.

FRANCO, G. B. et al. Relação qualidade da água e fragilidade ambiental da Bacia do Rio Almada, Bahia. Brazilian Journal of Geology, São Paulo, v. 42, suppl. 1, p. 114-127, 2013.

GARCIA, L. C. et al. Brazil's worst mining disaster: corporations must be compelled to pay the actual environmental costs. Ecological Applications, v. 27, n. 1, p. 5-9, 2017.

GOTTFRIED, R.; WEAR, D.; LEE, R. Institutional solutions to market failure on the landscape scale. Ecological Economics, v. 18, n. 2, p. 133-140, 1996.

GUERRA, C. Meio ambiente e trabalho no mundo do eucalipto. 2. ed. Belo Horizonte, Agência Terra, 1995.

HOLL, K. D.; AIDE, T. M. When and where to actively restore eco-systems? For. Ecol. Manage, v. 261, p. 1558-63, 2011.

LIMA, L. P. Z. et al. Análise da vulnerabilidade natural para implantação de unidades de conservação na microrregião da Serra de Carrancas, MG. Cerne, Lavras, v. 17, n. 2, p. 151-159, 2011.

LINDBORG, R. et al. A landscape perspective on conservation of semi-natural grasslands. Agriculture, Ecosystems \& Environment, v. 125, n. 1-4, p. 213-222, 2008.

MANNIGEL, A. R. et al. Fator erodibilidade e tolerância de perda dos solos do estado de São Paulo. Acta Scientiarum, Maringá, v. 24, n. 5, p. 1335-1340, 2002.

NUNES, et al. Enabling large-scale forest restoration in Minas Gerais state, Brazil. Environ. Res. Lett., v. 12, n. 044022, 2017.

PESQUISA DA PECUÁRIA MUNICIPAL. Disponível em: <https://www.ibge.gov.br/estatisticas/economicas/ agricultura-e-pecuaria/9107-producao-da-pecuaria-municipal.html>. Acesso em: ago. 2019.

PIRES, A. P. F. et al. Forest restoration can increase the Rio Doce watershed resilience. Perspectives in Ecology and Conservation, v. 15, n. 3, p. 187-193, 2017.

RAMOS, R. A. R.; MENDES, J. F. G. Avaliação de aptidão do solo para localização industrial: o caso de Valença. Revista Engenharia Civil, v. 10, n. 1, p. 7-29, 2001.

SALOMÃO, C. S. C. Sistemas agroflorestais como estratégia para restauração ecológica da Bacia do Rio Doce. Dissertação (Mestrado) - Universidade Federal de Minas Gerais (UFMG), Belo Horizonte, 2019.

SILVA JUNIOR, C. H. L. Lógica Fuzzy e Processo Analítico Hierárquico (AHP) aplicados ao Zoneamento de Áreas Suscetíveis a Deslizamentos: uma revisão. Revista Monografias Ambientais - Remoa. Revista do Centro de Ciências Naturais e Exatas - UFSM, v. 14, n. 3, p. 42-58, 2015.

SOARES FILHO, B. S.; RODRIGUES, H.; FOLLADOR, M. A hybrid analytical-heuristic method for calibrating land-use change models Environ. Modell Software, v. 43, p. 80-87, 2013.

SOARES FILHO, B. S. et al. Modelagem das Oportunidades Econômicas e Ambientais do Restauro Florestal sob - Novo Código Florestal. Impacto de políticas públicas voltadas à implementação do novo Código Florestal. Relatório de Projeto. Centro de Sensoriamento Remoto, UFMG, Belo Horizonte-MG, 2014. 
SOUZA, D. F. DE et al. Aplicação do método AHP-Fuzzy. ENCONTRO NACIONAL DOS ESTUDANTES DE MATEMÁTICA DA REGIÃO SUL, 2010. Porto Alegre/RS. Disponível em: <http://www.pucrs.br/edipucrs/erematsul/ comunicacoes/10DEBORAFERRODESOUZA.pdf>. Acesso em: 20 jan. 2013.

UFMG; UFV; FUNDAÇÃO RENOVA. Definição de áreas prioritárias para restauração florestal na Bacia do Rio Doce, 2018.

URIBE, D. et al. Integrating Stakeholder Preferences and GIS-Based Multicriteria Analysis to Identify Forest Landscape Restoration Priorities. Sustainability, v. 6, p. 935-951 2014.

VALENTE, R. O. A. Definição de áreas prioritárias para a conservação e preservação florestal por meio da abordagem multicritério em ambiente SIG, 2005. 121 f. Tese (Doutorado em Recursos Florestais) - Escola Superior de Luiz de Queiroz, Universidade de São Paulo, Piracicaba, 2005.

VALENTE, R. A.; VETTORAZZI, C. A. Multicriteria Decision Analysis for Prioritizing Areas for Forest Restoration. Cerne, v. 23, n. 1, p. 53-60, 2017.

VETTORAZZI, C. A. Avaliação multicritério em ambiente SIG, na definição de áreas prioritárias à restauração florestal visando à conservação dos recursos hídricos. 151 f. Tese (Livre Docência em Topografia) - Escola Superior de Luiz de Queiroz, Universidade de São Paulo, Piracicaba. 2006. 